\title{
Pain, healing and satisfaction of women after perineal repair with surgical glue and suture
}

\author{
Dor, cicatrização e satisfação da mulher após reparo perineal com cola cirúrgica e fio de sutura \\ Dolor, cicatrización y satisfacción de la mujer después de la reparación \\ perineal con pegamento quirúrgico e hilo de sutura
}

How to cite this article:

Marks PMT, Caroci-Becker A, Brunelli WS, Oliveira SG, Lima MOP, Riesco MLG. Pain, healing and satisfaction of women after perineal repair with surgical glue and suture. Rev Esc Enferm USP. 2020;54:e03588. doi: https://doi.org/10.1590/S1980-220X2018044203588

\section{Percela Moscoso Tence Marks ${ }^{1}$ \\ Adriana Caroci-Becker ${ }^{2}$ \\ Wesllanny Sousa Brunelli ${ }^{1}$ \\ Sheyla Guimarães de Oliveira ${ }^{1}$ \\ Marlise de Oliveira Pimentel Lima² \\ Maria Luiza Gonzalez Riesco ${ }^{3}$}

${ }^{1}$ Universidade de São Paulo, Escola de Enfermagem, Programa de Pós-Graduação em Enfermagem, São Paulo, SP, Brazil.

${ }^{2}$ Universidade de São Paulo, Escola de Artes, Ciências e Humanidades, Curso de Obstetrícia, São Paulo, SP, Brazil.

${ }^{3}$ Universidade de São Paulo, Escola de Enfermagem, Departamento de

Enfermagem Materno-Infantil e

Psiquiátrica, São Paulo, SP, Brazil.

\begin{abstract}
Objective: To compare the intensity of pain, the healing process and women's satisfaction with the repair of perineal trauma during vaginal delivery using surgical glue or suture. Method: Cross-sectional study aligned with a clinical trial conducted at a maternity in Itapecerica da Serra, São Paulo. The sample consisted of women who were evaluated between 10 and 20 days after delivery. The outcomes were analyzed according to the distribution of women in the experimental group (EG: perineal repair with Glubran-2 ${ }^{\circledR}$ surgical glue; $\mathrm{n}=55$ ) and in the control group (CG: perineal repair with Vicryl ${ }^{\circledR}$ suture thread; $n=55)$. Results: 110 puerperal women were evaluated. There was no difference between EG and CG regarding sociodemographic and clinical-obstetric characteristics. The intensity of perineal pain, assessed by the visual numeric scale was lower among women in the EG compared to the CG ( $\mathrm{p}<0.001$ ). According to the REEDA scale, there was no significant difference in perineal healing $(p=0.267)$ between EG and CG. The satisfaction of women with perineal repair, assessed using a five-point scale, was higher with the use of surgical glue $(\mathrm{p}=0.035)$. Conclusion: Surgical glue showed advantages in relation to perineal pain and greater satisfaction for women compared to the use of suture. The healing process was similar for both types of repair.
\end{abstract}

\section{DESCRIPTORS}

Obstetric Nursing; Natural Childbirth; Perineum; Pain; Wound Healing; Cola.
Corresponding author:

Percela Moscoso Tence Marks

Instituto Paulista de Ginecologia e Obstetrícia,

Consultório de Pré-natal

Rua Abílio Soares, 1125, Paraíso

CEP 04005-004 - São Paulo, SP, Brazil

percela@usp.br
Received: 10/16/2018

Approved: 09/26/2019 


\section{INTRODUCTION}

Perineal trauma occurs frequently in vaginal delivery and is strongly related to short- or long-term morbidities. Complications that occur during the healing process of the perineum from the first hours after delivery and even months or years later are common, such as pain, edema, hyperemia, ecchymosis, vaginal bleeding, infection and dehiscence, in addition to other morbidities, such as dyspareunia, urinary (UI) and anal (AI) incontinence and decreased pelvic floor muscle strength (PFMS) ${ }^{(1-3)}$.

A publication of the Brazilian Ministry of Health shows that $71.6 \%$ of women are submitted to episiotomy during vaginal delivery ${ }^{(4)}$. A national survey on labor and birth reports that $53.5 \%$ of women underwent episiotomy ${ }^{(5)}$. The frequency of perineal trauma varies internationally, especially in relation to episiotomy. In Asian countries, such as China and Taiwan, its rate exceeds 82\%, while in European countries, such as Sweden, Denmark and England, it occurs between $9.7 \%$ and $13 \%{ }^{(6)}$ of vaginal deliveries.

Perineal pain is one of the most common morbidities that occur in the puerperal period, affecting about one third of primiparous women after natural delivery, and is associated with the postpartum period and the presence of local trauma. The presence of perineal trauma increases the chance of having local pain in the primiparous women by about three times compared to the intact perineum ${ }^{(1)}$. Pain can be assessed using scales and questionnaires such as the Visual Numeric Scale (VNS) and the Visual Analog Scale (VAS) ${ }^{(7)}$. There is a recommendation for it to be evaluated before, during and after procedures and/or interventions, paying attention to their location, intensity and sensation. The perineal healing process can be evaluated after delivery using the REEDA perineal healing assessment instrument (redness, edema, ecchymosis, discharge, approximation). This instrument was developed by Davidson, in 1970, and later revised by Carey, in 1971, and Bolles, in $1972^{(8)}$.

Postpartum morbidities are also related to the type of perineal repair. There is a lack of standardization of the techniques and materials used, as some perform continuous or interrupted sutures with catgut or polyglycolic 910 suture thread, and others choose not to suture in some situations. Current evidence recommend the use of the continuous suture technique, as there is a reduction in pain and discomfort in the perineal region, less use of anesthetic during the procedure and improvement in healing on the 10th day after delivery ${ }^{(9)}$. Other publications have also shown an increase in women's satisfaction ${ }^{(10)}$.

Some authors believe that the fast absorbing Vicryl ${ }^{\infty}$ suture thread should be the first choice for suturing the perineum. This product has as main advantages the preservation of the tension force between 10 and 42 days and bactericidal action against Staphylococcus aureus and epidermidis ${ }^{(11-12)}$.

With technological advances, the surgical glue is another material that has been studied for the repair of surgical incision or tissue trauma. Since 1998, the Food and Drug Administration (FDA), from the United States of America, has approved the first adhesive surgical glue which contains cyanoacrylate acid, known as Dermabond ${ }^{\oplus}$, used to bring the skin closer. This agency also approved the use of surgical glue containing histoacryl acid. Recent studies have shown that surgical glue can be successfully applied to different skin and mucosal lesions, such as: lip sores, aphthous ulcers, facial injuries after Mohs surgery and nail skin lesions ${ }^{(13)}$.

The advantages for using the glue are the short application time, easier use and its hemostatic and bacteriostatic character. In addition, it is biodegradable and has adequate tensile strength ${ }^{(14)}$. However, due to the rapid polymerization of cyanoacrylate monomers, the product has a significant heat dissipation during use, which can result in the formation of a hardened and brittle film of glue at the application site ${ }^{(15)}$.

In order to reduce common morbidities during the puerperium, new materials and techniques are needed for better perineal repair.

Thus, the objective of this study was to compare the intensity of perineal pain, the healing process and satisfaction in postpartum women between 10 and 20 days after vaginal delivery, who underwent first and second degree lacerations repair or episiotomy with Glubran $-2^{\circledR}$ glue or with the fast absorbing Vicryl $1^{\bullet}$ suture thread.

\section{METHOD}

\section{STUdy TYPE}

This is a cross-sectional study on pain intensity, perineal healing and women's satisfaction with perineal repair, between 10 to 20 days after vaginal delivery. It is aligned with a controlled and randomized controlled trial, which used the Glubran- $2^{\infty}$ surgical glue and the fast absorbing Vicryl $1^{\oplus}$ suture thread in the perineal repair of women who had a vaginal delivery with first and second degree perineal lacerations or episiotomy, and has as title "Clinical trial on the use of surgical glue to repair episiotomies and perineal lacerations" and objective "to evaluate the effectiveness of Glubran- $2^{\infty}$ surgical glue in repairing episiotomy and first and second degree perineal lacerations in vaginal delivery".

\section{Population}

In the clinical trial, the participants were divided into four groups: Experimental Group 1 (EG1) - formed by parturients with first degree laceration submitted to perineal repair with Glubran- $2^{\infty}$ surgical glue; Experimental Group 2 (EG2) - formed by parturients with second degree laceration or episiotomy submitted to perineal repair with Glubran-2 ${ }^{\circ}$ surgical glue; Control Group 1 (CG1) - formed by parturients with first degree laceration submitted to continuous suture with fast absorbing Vicryl ${ }^{\circ}$ suture thread; Control Group 2 (CG2) - formed by parturients with second degree laceration or episiotomy submitted to continuous suture with fast absorbing $\mathrm{Vicryl}^{\top}$ suture thread. The sample was calculated to detect a significant minimum difference of two points in the pain score between the two perineal repair methods, which resulted in a minimum sample of 140 parturients, with 35 in each group. The clinical trial was conducted in three stages, preliminary to this study: Stage 1, performed during labor and delivery; Stage 2, between 12 and 24 hours after delivery; and Stage 3, between 36 and 48 hours after delivery. In this stage, the participant was informed about the cross-sectional study and about the date of return between 
10 and 20 days postpartum (Stage 4); that is, the data collected in Stage 4 corresponded to the cross-sectional study. In all stages, data were collected through medical records, interviews with participants and perineal evaluations.

\section{INCLUSION CRITERIA}

The inclusion criteria for the clinical trial were: being in labor and not having a previous vaginal delivery. Women who had vaginal delivery with intact perineum or with spontaneous third or fourth degree perineal lacerations, had a cesarean section, or dropout from the study were excluded. For the cross-sectional study, the following inclusion criteria were considered: having participated in the clinical trial and being evaluated between 10 to 20 days after delivery. Exclusion criteria were loss of participants who, although were part of the clinical trial, did not return to the service and did not accept home visits.

\section{Materials used}

The materials used in the clinical trial were the Glubran $-2^{\circledast}$ surgical glue, a cyanoacrylic-based synthetic glue, modified by the addition of a monomer and synthesized by the manufacturer, GEM S.r.l, in Italy. It is a medical surgical product that can be used on the skin, both internally and externally, in accordance with the requirements of the European Directive 93/42/EEC. The other material used in the CT was the fast absorbing Vicryl ${ }^{\oplus}$ suture thread (polyglactin 910), being a synthetic, sterile, absorbable surgical thread, composed of a polymer obtained from $90 \%$ glycolide and 10\% L-lactide, from the brand Ethicon - Johnson \& Johnson Produtos Professionais Ltda ${ }^{(16-17)}$.

\section{EXPOSURE AND OUTCOMES}

Exposure was considered as perineal repair with surgical glue or suture, which was performed in clinical teaching. As outcomes, pain intensity, perineal healing and women's satisfaction with perineal repair were considered, evaluated between 10 to 20 days postpartum. Considering the nature of exposure and outcomes, there was no possibility of performing blinding in clinical teaching, as both women and researchers could observe the type of perineal repair, during the evaluation of the healing process.

The intensity of perineal pain was assessed using the VNS, which consists of a horizontal line with values in centimeters from 0 to 10 , with zero being classified as painless and ten as the worst pain imaginable ${ }^{(18)}$. The woman received the scale and indicated the number corresponding to the intensity of the pain. For statistical analysis, pain was categorized as: painless (0), mild pain (1-4), moderate pain $(5-7)$ and severe pain $(8-10)^{(19)}$.

The healing process of the perineum was evaluated using the REEDA scale, which assesses the process of tissue recovery after perineal trauma through five healing items: redness, edema, ecchymosis, discharge and approximation of the wound edges (coaptation). For each item evaluated, a score from zero to three was assigned, with a maximum score of 15 corresponding to the worst healing result of the perineum ${ }^{(8)}$.
To measure redness (hyperemia), edema, ecchymosis and coaptation of the edges, the Peri-Rule ${ }^{\circledast}$ ruler was used. This tool is made of malleable plastic and graduated in centimeters, is recommended to measure the depth and extent of perineal trauma ${ }^{(20)}$. This ruler was wrapped in a layer of PVC film and reused after cleaning with soap and water, followed by antisepsis with $70 \%$ alcohol.

To assess women's level of satisfaction with the type of perineal repair, a scale with responses classified into five points was used, corresponding to: very dissatisfied, dissatisfied, indifferent, satisfied and very satisfied. For this evaluation, a mirror was offered for the woman to visualize her perineum.

Thus, the independent variables were the type of material used for perineal repair performed in clinical teaching and the dependent variables were pain and perineal healing and the woman's satisfaction with the repair.

\section{Data collect}

The study was carried out at the Vaginal Birth Center (VBC) of the Emergency Room and Municipal Maternity Zoraide Eva das Dores (ERMMZED), a reference service for pregnant women at usual risk, located in the city of Itapecerica da Serra, São Paulo, Brazil.

In 2017, the VBC met a demand of approximately 140 deliveries per month, 73\% natural deliveries and 27\% cesarean sections. Regarding perineal conditions, it was found that, among those who had a vaginal delivery, $43.7 \%$ had an intact perineum, $4.5 \%$ underwent episiotomy and $51.8 \%$ had perineal lacerations, with $65.7 \%$ first degree, $33.6 \%$ second degree and $0.7 \%$ third degree lacerations (source: statistics from the Vaginal Birth Center. Birth Registration, Itapecerica da Serra, 2017). The professionals responsible for assisting vaginal deliveries are obstetric nurses. Obstetricians are requested in the event of a complication.

Data collection from clinical teaching and the cross-sectional study was carried out at the study site. However, when the participant was unable to return to the service due to any difficulty, the data were collected at her home. The researchers in the cross-sectional study are also members of the clinical trial team and received training to perform perineal repair and to evaluate perineal outcomes. The data was collected using an instrument designed for the study.

\section{DATA ANALYSIS AND TREATMENT}

The storage and typing of the data recorded on the form was done in the database, and imported into Excel ${ }^{\circledR}$. The Statistical Package for the Social Sciences SPSS ${ }^{\oplus} 13.0$ software was used to perform the statistical analysis. In the descriptive analysis of continuous quantitative variables, analysis of variance (ANOVA) was used in order to analyze the differences between the groups' means and to calculate the central tendency and dispersion measures (mean and standard deviation). Pearson's chi-square test was used for categorical variables (contingency tables).

In the cross tabulation of the categorical analysis, the approximate chi-square test was used in the Monte Carlo 
simulation. In situations where $\mathrm{p}$ values $<0.05$ were observed, a chi-square residual test was performed in which $\mathrm{z}$ scores are obtained for each combination of the contingency table, with scores greater (2) or smaller (-2) than two considered significant. The comparisons, when significant, were carried out by means comparison tests using Sidak.

\section{ETHICAL ASPECTS}

The clinical trial was approved by the Research Ethics Committee from the Nursing School at the Universidade de São Paulo, protocol 2.384.491/2017) and followed all the determinations from Resolution 466/2012, of the National Health Council, ensuring that the human rights of those involved in the research were protected. The inclusion of women in the study occurred after signing the Informed Consent Form and the Assent Agreement for participants under 18 years old.

\section{RESULTS}

A total of 110 puerperal women were evaluated, 55 were in the control groups (CG), CG1 - 28 and CG2 - 27 of the clinical trial (perineal repair with Vicryl ${ }^{\varpi}$ suture thread) and
55 in the experimental groups (EG) with EG1 - 29 and EG2 - 26 (perineal repair with Glubran- $2^{\oplus}$ surgical glue).

The sociodemographic characteristics and the nutritional status of women involved in the study showed no significant difference between the groups, indicating homogeneity in relation to the analyzed variables.

The predominant and self-reported skin color was brown $(\mathrm{n}=57 ; 51.8 \%)$. Most women had completed high school $(\mathrm{n}=61 ; 55.5 \%)$, performed household activities $(\mathrm{n}=56 ; 50.9 \%)$ and maintained a stable union with a partner $(\mathrm{n}=93 ; 84.5 \%)$, in cohabitation ( $\mathrm{n}=84 ; 76.4 \%)$. Regarding nutritional status, most had adequate weight in pregnancy $(n=44 ; 41.5 \%)$, but more than $1 / 4$ of the women ( $n=28 ; 26.4 \%)$ were underweight (Table 1$)$.

The mean body mass index was $28.1(\mathrm{SD}=4.4)$ and 27.3 $(\mathrm{SD}=4.2)$, in the $\mathrm{CG}$ and $\mathrm{EG}$, respectively. The average age of women was $22.0(\mathrm{SD}=4.6)$ years old in the $\mathrm{CG}$ and 21.3 $(\mathrm{sd}=4.2)$ in the EG. The mean gestational age was 37.7 $(\mathrm{SD}=7.5)$ weeks in the $\mathrm{CG}$ and $39.3(\mathrm{SD}=1.1)$ weeks in the EG. Regarding the weight of the newborn, the average was 3,304.5 ( $\mathrm{SD}=408.1$ ) grams in the $\mathrm{CG}$ and 3,221.4 $(\mathrm{SD}=370.8)$ grams in the EG (data not shown in the table).

Table 1 - Characteristics of women in the total of the control groups (CG1 and CG2) and experimental groups (EG1 and EG2), according to categorical variables and p-value - Itapecerica da Serra, SP, Brazil, 2018.

\begin{tabular}{|c|c|c|c|c|c|c|c|}
\hline \multirow{2}{*}{ Characteristic } & \multicolumn{2}{|c|}{ Total CG } & \multicolumn{2}{|c|}{ Total EG } & \multicolumn{2}{|c|}{ Total } & \multirow{2}{*}{ p-value } \\
\hline & $\mathbf{n}$ & $(\%)$ & $\mathbf{n}$ & $(\%)$ & $\mathbf{n}$ & $(\%)$ & \\
\hline \multicolumn{8}{|l|}{ Skin color (race) } \\
\hline White & 15 & 27.3 & 17 & 30.9 & 32 & 29.1 & \\
\hline Brown & 25 & 45.4 & 32 & 58.2 & 57 & 51.8 & $0.143^{* A}$ \\
\hline Black & 14 & 25.5 & 5 & 9,1 & 19 & 17.3 & $0.592^{* \mathrm{~B}}$ \\
\hline Yellow & 1 & 1.8 & 1 & 1.8 & 2 & 1.8 & $0.162^{*} \mathrm{C}$ \\
\hline Total & 55 & 100 & 55 & 100 & 110 & 100 & \\
\hline \multicolumn{8}{|l|}{ Education } \\
\hline Incomplete Elementary School & 2 & 3.6 & 3 & 5.5 & 5 & 4.5 & \multirow{6}{*}{$\begin{array}{l}0.898^{* A} \\
0.347^{* \mathrm{~B}} \\
0.677^{* \mathrm{C}}\end{array}$} \\
\hline Complete Elementary School & 5 & 9.1 & 3 & 5.5 & 8 & 7.3 & \\
\hline Incomplete High School & 12 & 21.8 & 11 & 20.0 & 23 & 20.9 & \\
\hline Complete High School & 29 & 52.7 & 32 & 58.1 & 61 & 55.5 & \\
\hline Incomplete Higher Education & 3 & 5.5 & 4 & 7.3 & 7 & 6.4 & \\
\hline Complete Higher Education & 4 & 7.3 & 2 & 3.6 & 6 & 5.4 & \\
\hline Total & 55 & 100 & 55 & 100 & 110 & 100 & \\
\hline \multicolumn{8}{|l|}{ Occupation } \\
\hline Housewife & 26 & 47.3 & 30 & 54.5 & 56 & 50.9 & \multirow{3}{*}{$\begin{array}{l}0.726^{* * A} \\
0.748^{* * \mathrm{~B}} \\
0.951^{* * \mathrm{C}}\end{array}$} \\
\hline Paid work & 20 & 36.4 & 18 & 32.8 & 38 & 34.5 & \\
\hline Student & 9 & 16.3 & 7 & 12.7 & 16 & 14.6 & \\
\hline Total & 55 & 100 & 55 & 100 & 110 & 100 & \\
\hline \multicolumn{8}{|l|}{ Marital status } \\
\hline Has a partner & 50 & 90.9 & 43 & 78.2 & 93 & 84.5 & \multirow{3}{*}{$\begin{array}{l}0.112^{* * A} \\
0.604^{* * \mathrm{~B}} \\
0.200^{* * \mathrm{C}}\end{array}$} \\
\hline Has no partner & 5 & 9.1 & 12 & 21.8 & 17 & 15.5 & \\
\hline Total & 55 & 100 & 55 & 100 & 110 & 100 & \\
\hline Lives with a partner & 44 & 80.0 & 40 & 72.7 & 84 & 76.4 & \\
\hline Does not live with a partner & 11 & 20.0 & 15 & 27.3 & 26 & 23.6 & $\begin{array}{l}0.501^{* * A} \\
0.827^{* * \mathrm{~B}} \\
0.698^{* * \mathrm{C}}\end{array}$ \\
\hline Total & 55 & 100 & 55 & 100 & 110 & 100 & \\
\hline \multicolumn{8}{|c|}{ Nutritional status (during pregnancy) } \\
\hline Underweight & 14 & 26.9 & 14 & 25.9 & 28 & 26.4 & \multirow{5}{*}{$\begin{array}{c}0.588^{* *} \mathrm{~A} \\
0.366^{* *} \mathrm{~B} \\
0.749^{*} \mathrm{C}\end{array}$} \\
\hline Normal & 19 & 36.6 & 25 & 46.3 & 44 & 41.5 & \\
\hline Overweight & 10 & 19.2 & 10 & 18.5 & 20 & 18.9 & \\
\hline Obesity & 9 & 17.3 & 5 & 9.3 & 14 & 13.2 & \\
\hline Total & 52 & 100 & 54 & 100 & 106 & 100 & \\
\hline
\end{tabular}


In the assessment of the intensity of perineal pain reported by the woman, there was a statistical difference when comparing the $\mathrm{CG}$ with the $\mathrm{EG}$. In the analysis of numerical variables, women in EG had less intensity of perineal pain than women in CG ( $p=0.001)$. There was no significance when comparing perineal pain with the degree of perineal lacerations $(p=0.905)$ and in relation to the interaction between the type of perineal repair and the degree of laceration $(p=0.364)$. In the subgroups, the difference of means of 1.36 points was verified when comparing the $\mathrm{CG} 1(1.46$; $\mathrm{SD}=2.00)$ with the EG1 $(0.10 \mathrm{SD}=0.55)$ and 0.8 points between $\mathrm{CG} 2(1.14 \mathrm{SD}$ 2.12) and EG2 (0.34 SD=1.23) (Table 2).

The analysis of the total score of the REEDA scale showed no statistical difference when comparing the type of perineal repair $(\mathrm{p}=0.267)$ and the interaction between type of repair and degree of laceration ( $\mathrm{p}=0.673)$. However, there was significance when combining the REEDA scale score with the degree of perineal laceration $(\mathrm{p}<0.001)$, that is, women who had first degree laceration, regardless of the perineal repair performed, showed better results in the process of perineal healing than women who had second degree lacerations.

Regarding the coaptation of the perineal trauma edges, assessed by the REEDA scale, a statistical difference was observed when comparing the type of repair $(p=0.007)$ and the degree of laceration ( $p=0.0001)$, that is, in the $C G$, better results were obtained in coaptation than in the EG, and the first degree laceration, when compared with the second degree laceration, also had better coaptation results. Regarding the analysis of the type of repair vs degree of perineal laceration, there was no statistical difference $(\mathrm{p}=0.446)$ (Table 2).

To check where the statistical significance of this analysis was found, one used the $Z$ score. Thus, it was possible to verify that women who had second degree lacerations and underwent perineal repair with suture, compared with those submitted to perineal repair with surgical glue, showed better results in the process of perineal healing $(\mathrm{p}<0.05)$ (data not shown in table).

Table 2 - Statistics of the perineal pain intensity, healing process (REEDA) and coaptation of the edges of women in the control (CG1 and CG2) and experimental (EG1 and EG2) groups between 10 and 20 days after delivery, according to the type of perineal repair and the degree of perineal laceration - Itapecerica da Serra, SP, Brazil, 2018.

\begin{tabular}{|c|c|c|c|c|c|c|c|c|}
\hline \multirow[b]{2}{*}{ Variable } & \multirow[b]{2}{*}{ 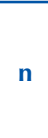 } & \multirow[b]{2}{*}{ Mean (s.d) } & & \multirow[b]{2}{*}{$\mathbf{n}$} & \multirow[b]{2}{*}{ Mean (s.d) } & \multicolumn{3}{|c|}{ p-value } \\
\hline & & & & & & $\begin{array}{l}\text { Type of } \\
\text { repair }\end{array}$ & $\begin{array}{l}\text { Degree of } \\
\text { laceration }\end{array}$ & $\begin{array}{l}\text { Type of repair } \\
\text { vs degree of } \\
\text { laceration }\end{array}$ \\
\hline \multicolumn{9}{|c|}{ Pain intensity } \\
\hline CG1 & 28 & $1.46(2.00)$ & EG1 & 29 & $0.10(0.55)$ & $0.001^{*}$ & $0.905^{* *}$ & $0.364^{* *}$ \\
\hline CG2 & 27 & $1.14(2.12)$ & EG2 & 26 & $0.34(1.23)$ & & & \\
\hline Total & 55 & $1.30(2,05)$ & Total & 55 & $0.21(0.93)$ & & & \\
\hline \multicolumn{9}{|l|}{ REEDA } \\
\hline CG1 & 28 & $0.17(0.47)$ & EG1 & 29 & $0.27(0.59)$ & $0.267^{*}$ & $<0.001^{* * * *}$ & $0.673^{*}$ \\
\hline CG2 & 27 & $0.62(0.88)$ & EG2 & 26 & $0.84(0.92)$ & & & \\
\hline Total & 55 & $0.40(0.73)$ & Total & 55 & $0.54(0.81)$ & & & \\
\hline \multicolumn{9}{|c|}{ Coaptation } \\
\hline CG1 & 28 & $0.07(0.26)$ & EG1 & 29 & $0.27(0.59)$ & $0.007^{*}$ & $<0.001^{*}$ & $0.446^{*}$ \\
\hline CG2 & 27 & $0.40(0.57)$ & EG2 & 26 & $0.76(0.65)$ & & & \\
\hline Total & 55 & $0.23(0.46)$ & Total & 55 & $0.50(0.66)$ & & & \\
\hline
\end{tabular}

In the analysis of satisfaction with perineal repair vs type of perineal repair, a significance was observed $(\mathrm{p}=0.035)$. Women who had perineal repair with glue reported greater satisfaction with the repair than women with suture, regardless of the degree of perineal laceration. In the CG, $34.6 \%$ $(\mathrm{n}=19)$ of the women reported being very satisfied, whereas this percentage was $54.5 \%(\mathrm{n}=30)$ among the women in the EG. In the CG, two women said they were dissatisfied and three very dissatisfied, while no woman from the EG reported dissatisfaction with perineal repair (Table 3).

Table 3 - Statistics of women's satisfaction in the control (CG) and experimental (EG) groups between 10 and 20 days after delivery Itapecerica da Serra, SP, Brazil, 2018.

\begin{tabular}{|c|c|c|c|c|c|}
\hline Repair satisfaction & & $\frac{\text { CG }}{\text { n (\%) }}$ & $\begin{array}{c}\text { EG } \\
n(\%)\end{array}$ & $\begin{array}{l}\text { Total } \\
\text { n (\%) }\end{array}$ & $p$-value \\
\hline \multirow{3}{*}{ Very dissatisfied } & Count & $3(5.5)$ & - & $3(3.0)$ & \multirow{16}{*}{$0.035^{*}$} \\
\hline & Expected count & 1.5 & 1.5 & 3.0 & \\
\hline & Adjusted residual & 1.8 & -1.8 & - & \\
\hline \multirow{3}{*}{ Dissatisfied } & Count & $2(3.6)$ & - & $2(2.0)$ & \\
\hline & Expected count & 1.0 & 1.0 & 2.0 & \\
\hline & Adjusted residual & 1.4 & -1.4 & - & \\
\hline \multirow{3}{*}{ Indifferent } & Count & $2(3.6)$ & $4(7.3)$ & $6(5.0)$ & \\
\hline & Expected count & 3.0 & 3.0 & 6.0 & \\
\hline & Adjusted residual & -0.8 & 0.8 & - & \\
\hline \multirow{3}{*}{ Satisfied } & Count & $29(52.7)$ & $21(38.2)$ & $50(45.5)$ & \\
\hline & Expected count & 25.0 & 25.0 & 50.0 & \\
\hline & Adjusted residual & 1.5 & -1.5 & - & \\
\hline \multirow{3}{*}{ Very satisfied } & Count & 19 (34.6) & $30(54.5)$ & $49(44.5)$ & \\
\hline & Expected count & 24.5 & 24.5 & 49.0 & \\
\hline & Adjusted residual & -2.1 & 2.1 & - & \\
\hline Total & Count & $55(100)$ & $55(100)$ & $110(100)$ & \\
\hline
\end{tabular}

${ }^{*}$ Chi-square test approximated by the Monte Carlo test. 
In the analysis of the type of perineal repair and degree of perineal laceration, one used the $Z$ score to assess the analysis. Women who underwent perineal repair with suture and who had second degree laceration showed greater dissatisfaction when compared to those who underwent repair with surgical glue $(\mathrm{p}=<0.05)$ (data not shown in the table).

\section{DISCUSSION}

The data from this study are part of a larger project of a randomized controlled trial on the use of surgical glue for the repair of perineal trauma in vaginal delivery. One sought to compare the intensity of pain, perineal healing and women's satisfaction with perineal repair using surgical glue or continuous suture between 10 and 20 days after delivery.

Women who participated in the control and experimental groups did not differ in terms of sociodemographic data and nutritional status. They were predominantly young, with education up to high school, self-reported brown color, with a partner, working in domestic activity and maintained a normal weight. These data are compatible with national and state surveys with puerperal women ${ }^{(21-22)}$.

The intensity of perineal pain was lower in the experimental groups ( $p>0.001$ ) when compared to the control groups, both in first and second degree lacerations. In a randomized clinical trial, using octyl-2-cyanocrylate surgical glue for first degree perineal repairs compared to the fast absorbing Vicryl ${ }^{\oplus}$ suture thread in 102 women (28 sutured with fast absorbing Vicryl ${ }^{\varpi}$ thread and 74 with surgical glue), octyl-2-cyanocrylate glue is not recommended for higher degree lacerations. In these cases, the author chose to suture with fast absorbing Vicryl ${ }^{\oplus}$ thread in the deeper layers and then finish with the glue. The women in this study were followed up over a period of 6 weeks in order to assess the result of glue repair and compare it with the suture. A lower score on the visual analog pain scale (1.7 versus $4.1 ; p>0.001)$ was observed immediately after the procedure, but with no difference between the two methods of repair regarding the pain score after 6 weeks of delivery. One concluded that the use of glue showed aesthetic and functional results similar to the suture and had advantages such as reduced perineal repair time, decreased pain, exemption from the need for local anesthesia and greater satisfaction for women ${ }^{(23)}$.

Another controlled clinical trial comparing skin repair in episiotomies, using the Dermabond ${ }^{\varpi}$ surgical glue and the fast absorbing Vicryl ${ }^{\varpi}$ suture thread, with 100 primiparous women, also showed a lower significant pain score during and after the procedure with the application of glue $(\mathrm{p}<0.005)^{(24)}$. The decrease in pain in the short and long term with the use of surgical glue, when compared to the suture, was again observed in a systematic review study ${ }^{(25)}$.

However, in a controlled clinical trial with 100 women, comparing the use of octyl-2-cyanoacrylate surgical adhesive glue $(n=48)$ with the fast absorbing polyglactin 910 suture thread $(n=53)$ in skin repair in episiotomies, there was no significant difference between the groups in the self-reported scores in relation to pain right after the procedure, nor after 7 and 30 days after delivery ${ }^{(26)}$.
In this study, there was no difference regarding the REEDA scale scores and the type of perineal repair, nor with the type of perineal repair and the degree of perineal laceration; however, the difference between the REEDA scale scores and the degree of laceration was significant $(p<0.001)$. Women with first degree laceration, regardless of the type of perineal repair performed, had better results on the REEDA scale scores than those with second degree laceration. In a randomized longitudinal study conducted in India, there was no significant difference in the healing process between the two episiotomy skin repair methods ${ }^{(24)}$.

In the perineal coaptation item evaluated by the REEDA scale, a significant difference was observed when comparing the type of perineal repair $(\mathrm{p}=0.007)$ and the degree of perineal trauma ( $\mathrm{p}=0.0001)$; that is, women who had second degree laceration and who underwent perineal repair with suture, compared to those who underwent perineal repair with surgical glue, had better results in the perineal healing process $(\mathrm{p}<0.05)$. A review study showed no difference in skin coaptation between suture or surgical glue repair ${ }^{(25)}$.

Women who had perineal repair performed with glue showed greater satisfaction with the repair than women sutured, regardless of the degree of perineal laceration $(\mathrm{p}=0.035)$.

It is important to contribute to quality care and the consequent satisfaction of women during delivery and postpartum. Therefore, performing procedures that reduce fear and improve women's satisfaction with delivery has been the goal of humanization of childbirth programs ${ }^{(27-28)}$.

Perineal repair with surgical glue can reduce the woman's pain intensity and provide greater satisfaction with perineal repair and with the whole experience in relation to delivery and postpartum. The satisfaction of women with perineal repair using surgical glue was also observed in other studies ${ }^{(23-25,29)}$. There is a growing concern in assessing the satisfaction of users of health services, as this variable can identify existing gaps and develop improvements in care ${ }^{(24,30)}$.

The use of surgical glue as an option for perineal repair of first degree lacerations and perineal skin in second degree lacerations was recently recommended by the American College of Obstetricians and Gynecologists as it provides less time for the repair, lower referred pain score and greater satisfaction with the result. It is worth considering that it is a level B recommendation, in which data are obtained from studies with less robust meta-analysis or from a single randomized study or from non-randomized studies ${ }^{(31)}$.

A limitation of this research refers to the cross-sectional design, which does not allow a more comprehensive analysis of dependent variables at other times in the puerperium, such as 30 or more days after delivery, to assess long-term repercussions that may arise from the use of surgical glue for perineal repair of first and second degree lacerations. Thus, a recent publication recommends that intervention studies for the management of perineal trauma related to delivery evaluate as main outcomes self-reported pain, healing process and quality of life, encompassing the satisfaction declared by continuous scales with the proposed procedure, and sexual dysfunction ${ }^{(32)}$. Another limitation is the selection bias due to the non-return, even after telephone contact, of study 
group participants who might not have been satisfied with the repair, although the reasons alleged after telephone contact were housing outside the urban perimeter and absence of financial conditions for transportation to return to the maternity hospital.

There are few studies which evaluated the healing process between 10 and 20 days after the use of surgical glue for perineal repair ${ }^{(8,29)}$. Thus, this study is a basis for further research to be carried out in order to show the benefits and harms of the use of surgical glue in perineal repair.

Regarding the implications for the practice, it was found that Glubran- $2^{\oplus}$ surgical glue is a viable alternative for decreasing perineal pain and increasing women's satisfaction with perineal repair, facilitating the daily activities of the puerperal woman. However, further studies must be conducted with different types of glue to support or not these findings. One also suggests that dyspareunia, sexual function, urinary incontinence and pelvic floor muscle strength be evaluated, in addition to cost analysis.

\section{CONCLUSION}

The use of Glubran- $2^{\circledast}$ surgical glue for perineal repair compared to the use of $\mathrm{Vicryl}^{\oplus}$ suture thread, demonstrated positive outcomes in in relation to decreased pain intensity and greater satisfaction of women with perineal repair. There was no statistical significance between the type of repair and the healing process between 10 to 20 days postpartum. Surgical glue is a clinically viable option for perineal repair.

\section{RESUMO}

Objetivo: Comparar a intensidade da dor, o processo de cicatrização e a satisfação da mulher com o reparo do trauma perineal no parto normal por meio de cola cirúrgica ou fio de sutura. Método: Estudo transversal alinhado a um ensaio clínico realizado na maternidade de Itapecerica da Serra, São Paulo. A amostra foi constituída por mulheres que foram avaliadas entre 10 a 20 dias após o parto. Os desfechos foram analisados segundo a distribuição das mulheres no grupo experimental (GE: reparo perineal com cola cirúrgica Glubran $\left.-2^{\circledR} ; n=55\right)$ e no grupo controle (GC: reparo perineal com fio Vicryl $\left.{ }^{\circledR} ; n=55\right)$. Resultados: Foram avaliadas 110 puérperas. Não houve diferença entre GE e GC quanto às características sociodemográficas e clínico-obstétricas. A intensidade da dor perineal, avaliada pela escala visual numérica, foi menor entre as mulheres do GE em comparação ao GC (p<0,001). Segundo a escala REEDA, não houve diferença significativa na cicatrização perineal $(p=0,267)$ entre GE e GC. A satisfação das mulheres com o reparo perineal, avaliada por escala de cinco pontos, foi maior com o uso da cola cirúrgica ( $p=0,035)$. Conclusão: A cola cirúrgica mostrou vantagens em relação à dor perineal e maior satisfação das mulheres comparada com o uso do fio de sutura. O processo de cicatrização foi similar nos dois tipos de reparo.

\section{DESCRITORES}

Enfermagem Obstétrica; Parto Normal; Períneo; Dor; Cicatrização; Cola.

\section{RESUMEN}

Objetivo: Comparar la intensidad del dolor, el proceso de cicatrización y la satisfacción de la mujer con la reparación del trauma perineal durante el parto normal utilizando pegamento quirúrgico o hilo de sutura. Método: Estudio transversal anidado a un ensayo clínico realizado en el hospital-maternidad de Itapecerica da Serra, São Paulo. La muestra consistió en mujeres que fueron evaluadas entre 10 y 20 días después del parto. Los resultados se analizaron según la distribución de las mujeres en el grupo experimental (GE: reparación perineal con pegamento quirúrgico Glubran $\left.-2^{\circledR} ; n=55\right)$ y en el grupo control (GC: reparación perineal con hilo Vicryl ${ }^{\circledR}$; $\mathrm{n}=55$ ). Resultados: Se evaluaron 110 mujeres en el postparto. No hubo diferencia entre GE y CG en cuanto a las características sociodemográficas y clínico-obstétricas. La intensidad del dolor perineal, evaluada mediante la escala numérica visual, fue menor entre las mujeres del GE en comparación con aquellas del GC ( $p<0,001)$. Según la escala REEDA, no hubo diferencias significativas en la cicatrización perineal $(\mathrm{p}=0,267)$ entre el GE y GC. La satisfacción de las mujeres con la reparación perineal, evaluada mediante una escala de cinco puntos, fue mayor con el uso de pegamento quirúrgico ( $\mathrm{p}=0,035)$. Conclusión: El pegamento quirúrgico mostró ventajas con relación al dolor perineal y mayor satisfacción de las mujeres, en comparación con el hilo de sutura. El proceso de cicatrización fue similar para ambos tipos de reparación.

\section{DESCRIPTORES}

Enfermería Obstétrica; Parto Normal; Perineo; Dolor; Cicatrización de Heridas; Cola.

\section{REFERENCES}

1. Francisco AA, Kinjo MH, Bosco CS, Silva RL, Mendes EPB, Oliveira SMJV. Association between perineal trauma and pain in primiparous women. Rev Esc Enferm USP. 2014;48(n.spe):39-44. DOI: http://dx.doi.org/10.1590/S0080-623420140000600006

2. Naidu M, Sultan AH, Thakar R. Reducing obstetric anal sphincter injuries using perineal support: our preliminary experience. Int Urogynecol J. 2017;28(3):381-9. DOI: http://dx.doi.org/10.1007/s00192-016-3176-4.

3. Paiva CSB, Oliveira SMJV, Francisco AA, Luana R, Mendes EPB, Steen M. Length of perineal pain relief after ice pack application: a quasiexperimental study. Women Birth. 2016;29(2):117-22. DOI: http://dx.doi.org/10.1016/j.wombi.2015.09.002

4. Brasil. Ministério da Saúde; Secretaria de Ciência, Tecnologia e Insumos Estratégicos. Pesquisa Nacional de Demografia e Saúde da Criança e da Mulher [Internet]. Brasília; 2009 [citado 2018 set. 29]. Disponível em: http//bvsms.saude.gov.br/bvs/publicações/pnds_ crianca_mulher.pdf

5. Leal MC, Pereira APE, Domingues RMSM, Theme Filha MM, Dias MAB, Pereira MN, et al. Obstetrician interventions during labor and childbirth in Brazilian low-risk women. Cad Saúde Pública. 2014;30 Supl.1:S17-32. DOI: http://dx.doi.org/10.1590/0102311X00151513

6. Graham ID, Carroli G, Davies C, Medves JM. Episiotomy rates around the world: an update. Birth. 2005;32(3):219-23. DOI: https://doi. org/10.1111/j.0730-7659.2005.00373.x

7. Nilsen E, Sabatino H, Lopes MHBM. The pain and behavior of women during labor and the different positions for childbirth. Rev Esc Enferm USP [Internet]. 2011 [cited 2018 Oct 16];45(3):557-65. Available from: http://www.scielo.br/scielo.php?script=sci_arttext\&pid=S0080$62342011000300002 \& \operatorname{lng}=\mathrm{en} \& \mathrm{nrm}=\mathrm{iso} \& \operatorname{lng}=\mathrm{en}$ 
8. Davidson N. REEDA: evaluating post partum healing. J Nurse Midwifery. 1974;19(2):6-8. DOI: https://doi.org/10.1111/j.1542-2011.1974. tb00384.x

9. Kettle C, Dowswell T, Ismail KM. Continuous and interrupted suturing techniques for repair of episiotomy or second degree tears. Cochrane Database Syst Rev. 2012;(11):CD000947. DOI: http://dx.doi.org/10.1002/14651858.CD000947.pub3

10. Brasil. Ministério da Saúde; Comissão Nacional de Incorporação de Tecnologias no SUS. Diretriz Nacional de Assistência ao Parto Normal [Internet]. Brasília; 2016 [citado 2018 set. 29]. Disponível em: http://conitec.gov.br/images/Consultas/2016/Relatorio_DiretrizPartoNormal_CP.pdf

11. Barros M, Gorgal R, Machado AP, Correia A, Montenegro N. Princípios básicos em cirurgia. Acta Med Port. 2011;24(S4):1051-6.

12. Kettle C, Tohill S. Perineal care. BMJ Clin Evid [Internet]. 2015 [cited 2018 Oct 16];2015:1401. Available from: https://www.ncbi.nlm. nih.gov/pmc/articles/PMC4356152/

13. Strauss EJ, Weil WN, Jordan C, Paksima N. A prospective, randomized, controlled trial of 2-octylcyanoacrolate versus suture repair for nail bed injuries. J Hand Surg Am. 2008;33(2):250-3. DOI: https://doi.org/10.1016/j.jhsa.2007.10.008

14. Singh PK, Degala S, Shetty S, Rai VS, Das A. To evaluate the efficacy and effectiveness of N-butyl-2-cyanoacrylate glue (TRU SEAL) in closure of oral and maxillofacial laceration and surgical incisions. J Maxillofac Oral Surg. 2019;18(1):131-8. DOI: http://dx.doi. org/10.1007/s12663-018-1111-6

15. Bragat V, Becker ML. Degradable adhesives for surgery and tissue engineering. Biomacromolecules. 2017;18:3009-39. DOI: http://dx.doi. org/10.1021/acs.biomac.7b00969

16. Greenberg JA, Clark RM. Advances in suture material for obstetric and gynecologic surgery. Rev Obstet Gynecol. 2009;2(3):146-58.

17. Kull S, Martinelli I, Briganti E, Losi, P, Spiller D, Tonlorenzi S, et al. Glubran2 surgical glue: in vitro evaluation of adhesive and mechanical properties. J Surg Res. 2008;157(1):15-21. DOI: http://dx.doi.org:10.1016/j.jss.2009.01.034

18. McCaffery M, Beebe A. Pain: clinical manual for nursing practice. St. Louis: Mosby; 1989.

19. Pimenta CAM, Cruz DALM, Santos JLF. Instrumentos para avaliação da dor: o que há de novo em nosso meio. Arq Bras Neurocir. 1998;7(1):15-24.

20. Metcalfe A, Tohill S. Perineal tear assessment and the development of the Peri-rule. In: Henderson C, Bick D. Perineal care: an international issue. Nottingham: Quay Books; 2005. p. 87-97.

21. Instituto Brasileiro de Geografia e Estatística. Perfil das Mães 2000 [Internet]. Rio de Janeiro: IBGE; 2000 [citado 2018 set. 29]. Disponível em: https://ww2.ibge.gov.br/home/estatistica/populacao/perfil_maes/defaulttab.shtm

22. Diniz CSG, Batista LE, Kalckmann S, Schlithz AOC, Queiroz MR, Carvalho PCA. Desigualdades sociodemográficas e na assistência à maternidade entre puérperas no Sudeste do Brasil segundo cor da pele: dados do Inquérito Nacional Nascer no Brasil (2011-2012). Saúde Soc. 2016;25(3):561-72. DOI: http://dx.doi.org/10.1590/s0104-129020162647

23. Feigenberg T, Maor-Sagie E, Zivi E, Abu-Dia M, Bem-Meir A, Sela HY, et al. Using adhesive glue to repair first degree perineal tears: a prospective randomized controlled trial. Bio Med Res Int. 2014;2014:526590. DOI: http://dx.doi.org/10.1155/2014/526590

24. Chamariya S, Prasad M, Chauhan A. Comparison of dermabond adhesive glue with skin suture for repair of episiotomy. Int J Reprod Contracept Obstet Gynecol. 2016;5(10):3461-5. DOI: http//dx.doi.org/10.18203/2320-1770.ijrcog20163423

25. Seijmonsbergen-Schermers A, Sahami S, Lucas C, Jonge A. Non suturing or skin adhesives versus suturing of the perineal skin after childbirth: a systematic review. Birth. 2015;42(2):100-15. DOI: https://doi.org/10.1111/birt.12166

26. Mota R, Costa F, Amaral A, Oliveira F, Santos CC, Ayres-de-Campos D. Skin adhesive versus subcuticular suture for perineal skin repair after episiotomy: a randomized controlled trial. Acta Obstet Gynecol Scand. 2009;88(6):660-6. DOI: https://doi. org/10.1080/00016340902883133

27. Brasil. Ministério da Saúde; Secretaria de Ciência, Tecnologia e Insumos Estratégicos, Departamento de Gestão e Incorporação de Tecnologias em Saúde. Diretrizes nacionais de assistência ao parto normal: versão resumida. Brasília: Ministério da Saúde; 2017.

28. World Health Organization. WHO recommendations: intrapartum care for a positive childbirth experience. Geneva: WHO; 2018.

29. Teixeira TT. Cola adesiva cirúrgica no reparo de lacerações perineais de primeiro grau no parto normal: estudo piloto aleatorizado controlado [dissertação]. São Paulo: Universidade de São Paulo; 2018 [citado 2019 jun. 21]. Disponível em: http://www.teses.usp.br/ teses/disponiveis/7/7141/tde-23112018-130437/pt-br.php

30. Al-Abri R, Al-Balushi A. Patient Satisfaction Survey as a Tool Towards Quality Improvement. Oman Med J. 2014;29(1):3-7. DOI:10.5001/ omj.2014.02

31. Waldman R. ACOG Practice Bulletin $n^{\circ} .198$ : prevention and management of obstetric lacerations at vaginal delivery. Obstet Gynecol. 2019;133(1):185. DOI: 10.1097/AOG.0000000000003041

32. Pergialiotis V, Durnea C, Elfituri A, Duffy JMN, Doumouchtsis SK. Do we need a core outcomes at for childbirth perineal trauma research? A systematic review of outcome reporting in randomized trials evaluating the management of childbirth trauma. BJOG. 2018;125(12):152231. DOI: http://dx.doi.org/10.1111/1471-0528.15408

Financial support:

Fundação de Amparo à Pesquisa do Estado de São Paulo (FAPESP). Conselho Nacional para o Desenvolvimento Científico e Tecnológico (CNPq). 